\title{
Encysted Spermatic Cord Hydrocele in Adults: A Case Report and Review of the Literature
}

\section{Yetişkinlerde Spermatik Kord Hidrosel: Olgu Sunumu ve Literatürün Gözden Geçirilmesi}

\author{
Barış Esen ${ }^{1}$, Serdar Sarıdemir ${ }^{2}$, Gulbin Guleryuz Bolsu ${ }^{3}$, Ayşe Ceren Doğanözü ${ }^{4}$ \\ ${ }^{1}$ Haymana Devlet Hastanesi, Üroloji \\ ${ }^{21}$ Haymana Devlet Hastanesi, Genel Cerrahi \\ ${ }^{31}$ Haymana Devlet Hastanesi, Radyoloji \\ ${ }^{41}$ Haymana Devlet Hastanesi, Anestezi Ve Reanimasyon
}

Dergiye Ulaşma Tarihi: 04,06,2020 Dergiye Kabul Tarihi:17,07,2020 Doi: 10.5505/aot.2020.70037

\section{ÖZET}

Spermatik kord hidrosel $(\mathrm{SCH})$, testisler fetal gelişim sırasında skrotuma inerken, processus vaginalis'in (PV) kapanması esnasında bir anormallikten kaynaklanır. Testis üzerindeki spermatik kord boyunca kapalı bir sıvı toplanmasıdır. İki tür SCH vardır. "Encysted" tipi hem proksimal hem de distal uçlarda kapalıdır ve periton boşluğu ile iletişim kurmaz. Füniküler tip iç inguinal halkada proksimal kaynaklıdır ve distal olarak kapalıdır, bu nedenle periton boşluğu ile iletişim kurar. Literatürde olguların çoğu pediyatrik hastalarda bildirilmiştir ve erişkinlerde SCH oldukça nadirdir. Burada inguinal şişlik ve aralıklı kasık ağrısı ile başvuran 51 yaşında bir erkekte encysted tipte bir SCH olan bir olguyu sunuyoruz.

Anahtar Kelimeler: Hidrosel, Kord hidrosel, Encysted hidrosel, Füniküler hidrosel

\section{ABSTRACT}

Spermatic cord hydrocele ( $\mathrm{SCH}$ ) is caused by an aberration in the closure of the processus vaginalis (PV) as the testicles descend into scrotum during fetal development. It is an enclosed fluid collection along the spermatic cord above the testicle. There are two types of SCH. The "encysted" type is closed at both proximal and distal ends and does not communicate with the peritoneal cavity. Funicular type is patent proximally at the internal inguinal ring and closed distally, thus communicates with the peritoneal cavity. In the literature, most of the cases were reported in pediatric patients and SCH in adults is extremely rare. Herein we present a case with an encysted type of SCH in a 51-year-old male presenting with inguinal swelling and intermittent groin pain.

Keywords: Hydrocele, Cord hydrocele, Encysted hydrocele, Funicular hydrocele

\section{Case Report}

A 51-year-old male presented with swelling in the left inguinal region and intermittent dull aching pain for the last 2 months. The patient noted that his pain had progressed for the last 2 weeks. Patient had no previous malignancy or systemic disease. There was no history of abdominal pain, vomiting, fever or constipation. Abdominal examination and bowel sounds were normal. Genitalia examination was normal. Transillumination test and cough impulse tests were negative. Local physical examination revealed a globular, soft and mobile swelling along the spermatic cord. The swelling was completely separate from the testicle. All baseline blood tests, testicular tumor markers and systemic evaluation were normal.Ultrasound (US) examination showed a $72 * 11-\mathrm{mm}$,septated and well demarcated anechoic cystic lesion along spermatic cord (Figure 1).The anechoic mass was avascular when evaluated by color Doppler US. No bowel wall signature or peristalsis was observed. There was no scrotal hydrocele in theUS examination.

Left inguinal exploration was performed. A cystic structure that was attached to spermatic cord was observed (Figure 2A and 2B).After careful dissection of the cyst from the spermatic cord, it was shown that both ends of the cyst were closed. The encysted type $\mathrm{SCH}$ with a size of $6.5^{*} 1,5^{*} 1 \mathrm{~cm}$ was enblockly excised (Figure 2C). Aspiration of 
the contents of the cyst revealed an amber colored fluid. Biochemical analysis of the fluid revealed lower total protein $(3.8 \mathrm{~g} / \mathrm{dl})$ and albumin $(2.9 \mathrm{~g} / \mathrm{dl})$ levels than blood serum. Other biochemical results (such as electrolytes, cre, urea, alt, ast, uric acid levels) were almost similar with blood serum. Histopathological examination of the cyst wall was consistent with a benign cystic structure. No postoperative complication was observed. Patient was symptom-free at postoperative 1 . month.

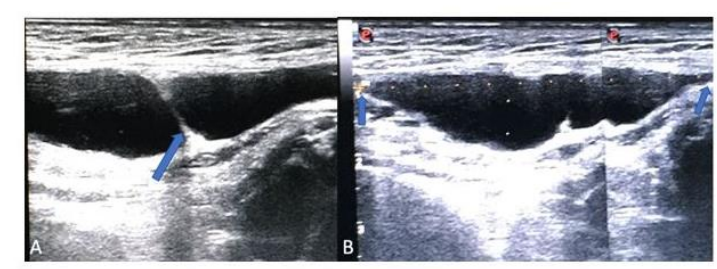

Figure 1: Longitudinal scan of left inguinal spermatic cord and encysted spermatic cord hydrocele. A: Septation of spermatic cord hydrocele (arrow). B: Proximal and distal ends of spermatic cords were enclosed. (artolws)

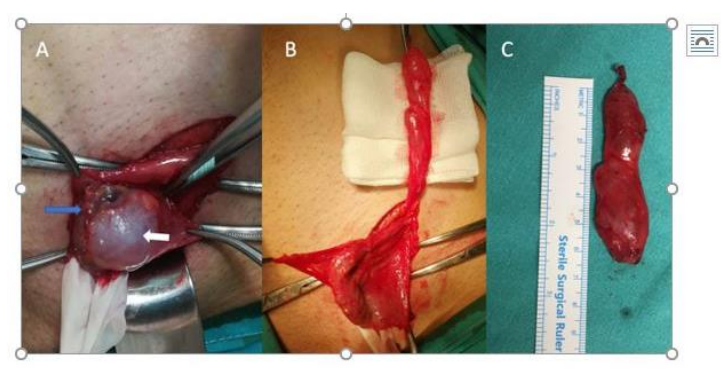

Figure 2: Intraoperative images of the spermatic cord hydrocele and the spermatic cord. A: Spermatic cord hydrocele (white arrow) was attached to the spermatic cord (blue arrow). B: Spermatic cord hydrocele was dissected from the spermatic cord. C: Excised specimen (Both ends were closed - indicating encysted type of $\mathrm{SCH}$ )

\section{Discussion}

Embryologically, peritoneum bulges into the inguinal canal during third month of gestation and forms PV. As testicles descend into scrotum between 28 and 32 weeks of gestation, they carry two layers of peritoneum and forms a canal between scrotum and peritoneum which is defined as PV. Near the time of birth, processus should close at both ends; just above the testicle and at the internal inguinal ring. The processus between the two constrictions should undergo involution(1).However, as many as $20 \%$ of the population PV remains intact but mostly remains asymptomatic throughout life(1). If there is a widely patent PV containing intraperitoneal contents (bowel, omentum etc.), it is called "indirect inguinal hernia". If patent PV contains only intraperitoneal fluid, it is defined as "communicating hydrocele". If PV is obliterated distally but stays patent through internal inguinal ring, it is defined as "funicular type $\mathrm{SCH}$ ". "Encysted type of SCH" occurs if PV between two constrictions does not undergo involution.

Spermatic cord hydrocele usually presents as an inguinal bulge which can be difficult to differentiate from other lesions in the groin such as incarcerated inguinal hernia, paratesticular masses (cyst or tumour), inguinal lymphadenopathy, primary tumors of spermatic cord or an ectopic testis. In funicular $\mathrm{SCH}$, bulging may increase with straining or crying and may resolve spontaneously. An encysted SCH does not change in its size and shape with increased intraabdominal pressure. US features of $\mathrm{SCH}$ were reported in a case series of 27 children by Rathaus et al. Oval, anechoic, well demarcated and avascular masses were observed in all cases. Internal septation was observed in 4/27 (16\%) of patients.The authors emphasized that no abdominal contents should be identified in the lesion.(2) US can differentiate between encysted type and funicular type of $\mathrm{SCH}$ by evaluating continuity of the lesion with peritoneum at the internal inguinal ring. Most data about $\mathrm{SCH}$ have come from case reports in pediatric patients and data about $\mathrm{SCH}$ in adults is scarce. 
Table 1: Summary of Reported Adult Cases With Spermatic Cord Hydrocele

\begin{tabular}{|c|c|c|c|c|c|c|c|}
\hline $\begin{array}{l}\text { Author- } \\
\text { year }\end{array}$ & $\begin{array}{l}\text { Number } \\
\text { of cases }\end{array}$ & Age & Presentingsymptoms & $\begin{array}{c}\text { Site of } \\
\text { thelesion }\end{array}$ & Size $(\mathbf{c m})$ & Type of SCH & Treatment \\
\hline $\begin{array}{l}\text { Busigo et. } \\
\text { al. } \\
(2007)(3)\end{array}$ & 3 & $\begin{array}{ll}\text { 1. } & 56 \\
\text { 2. } & 65 \\
\text { 3. } & 69\end{array}$ & $\begin{array}{ll}\text { 1. } & \text { None-Incidental } \\
\text { 2. None-Incidental } \\
\text { 3. None-Incidental }\end{array}$ & $\begin{array}{ll}\text { 1. } & \text { Bilateral } \\
\text { 2. } & \text { Right } \\
\text { 3. } & \text { Right }\end{array}$ & $\begin{array}{ll}1 . & \text { na } \\
\text { 2. } & 4 * 2.5 * 1,2 \\
\text { 3. } & \text { na }\end{array}$ & $\begin{array}{ll}1 . & \text { na } \\
\text { 2. } & \text { Funicular } \\
\text { 3. } & \text { na }\end{array}$ & $\begin{array}{ll}\text { 1. } & \text { Follow-up } \\
\text { 2. } & \text { Surgicalexcision } \\
\text { of cyst } \\
\text { 3. } & \text { Follow-up }\end{array}$ \\
\hline $\begin{array}{l}\text { Wani et al. } \\
(2009)(4)\end{array}$ & 1 & 36 & $\begin{array}{l}\text { Inguinal swelling- } \\
\text { pain }\end{array}$ & Right & $5 * 2.3 * 1$ & Encysted & $\begin{array}{l}\text { Surgical excision of } \\
\text { cyst }\end{array}$ \\
\hline $\begin{array}{l}\text { Manimarian } \\
\text { et. Al. } \\
(2014)(6)\end{array}$ & 1 & 60 & $\begin{array}{l}\text { Inguinal swelling- } \\
\text { pain }\end{array}$ & Left & $\begin{array}{l}4 \quad \mathrm{~cm} \text { in } \\
\text { diameter }\end{array}$ & Encysted & $\begin{array}{ll}\text { Left } & \text { high } \\
\text { orchidectomy } & \end{array}$ \\
\hline $\begin{array}{l}\text { Garg K.M. } \\
(2016)(5)\end{array}$ & 3 & $\begin{array}{ll}\text { 1. } & 23 \\
\text { 2. } & 26 \\
\text { 3. } & 32\end{array}$ & $\begin{array}{ll}\text { 1. } & \text { Inguinal swelling } \\
\text { 2. } & \text { Ingiinal swelling } \\
\text { 3. } & \text { Inguinal } \\
& \text { swelling-pain }\end{array}$ & $\begin{array}{ll}\text { 1. } & \text { na } \\
\text { 2. } & \text { na } \\
\text { 3. } & \text { Left }\end{array}$ & $\begin{array}{ll}\text { 1. } & \text { na } \\
\text { 2. } & \text { na } \\
\text { 3. } & 2.5 * 2\end{array}$ & $\begin{array}{ll}\text { 1. } & \text { Encysted } \\
\text { 2. } & \text { Encysted } \\
\text { 3. } & \text { Funicular }\end{array}$ & $\begin{array}{ll}\text { 1. } & \text { Surgical } \\
\text { excision of cyst } \\
\text { 2. Surgical } \\
\text { excision of cyst } \\
\text { 3. Surgical } \\
\text { excision of cyst } \\
\text { and propylene } \\
\text { mesh placement }\end{array}$ \\
\hline $\begin{array}{l}\text { Mahapatra } \\
\text { et. al. } \\
(2015)(7)\end{array}$ & 1 & 22 & Inguinal swelling & Left & $2.6 * 2.2 * 1.5$ & Encysted & $\begin{array}{l}\text { Surgical excision of } \\
\text { cyst }\end{array}$ \\
\hline $\begin{array}{l}\text { Currentcase } \\
(2020)\end{array}$ & 1 & 51 & $\begin{array}{l}\text { Inguinal swelling- } \\
\text { pain }\end{array}$ & Left & $6.5 * 1.5 * 1$ & Encysted & $\begin{array}{l}\text { Surgical excision of } \\
\text { cyst }\end{array}$ \\
\hline
\end{tabular}

na: non-applicable

In 2007, Busigo et al. reported 3 adultcaseswith SCH. Allthreecases had pasthistories of malignanciesandnone had complaints of pain. Theage of thepatientswere 56, 65 and 69 years, respectively. These patients were suspected for possible metastatic disease or any other inguinal mass and monitored with serial CT scans. No progression was observed during follow up and no further surgery was required. (3) Wani et al.
Reported an other adult case of SCH in a 36year-old male, presenting with groin pain and swelling. They performed right inguinal exploration and excised the encysted hydrocele of spermatic cord.(4) In another case series, 3 adult patients with $\mathrm{SCH}$ were reported by Garg K.M. Patients were 23, 26 and 32 years old, respectively. All patients had complaints of groin pain. 2 cases had encysted type and 1 case had funicular type of SCH. Excision of 
$\mathrm{SCH}$ was performed in patients with encysted type of SCH. The patient with funicular type of $\mathrm{SCH}$ underwent a repair of posterior wall of inguinal canal by propylene mesh placement besides excision of the $\mathrm{SCH}$.(5) Manimarian et al. reported a $\mathrm{SCH}$ in a 60-year-old patient, mimicking incarcerated inguinal hernia. The patient suffered from intermittent dullaching pain for 3 days. Left inguinal exploration was performed and a cystic structure which was attached to spermatic cord was observed. Left testis was found to be small and atrophic and left high orchidectomy was done along with resection of the cyst.(6) Mahapatra et. al. Reported an other 22-year-old adult case with an encysted type of SCH. Patient was treated with excision of the $\mathrm{SCH}$ without any complications.(7) Here in, we present a case with encysted type of SCH in 51-year-old male who presented with left inguinal swelling and pain. Similar with previous case reports,

\section{References}

1. Martin LC, Share JC, Peters C, Atala A. Hydrocele of the spermatic cord: embryology and ultrasonographic appearance. Pediatr Radiol. 1996;26(8):528-30.

2. Rathaus V, Konen O, Shapiro M, Lazar L, Grunebaum M, Werner M. Ultrasound features of spermatic cord hydrocele in children. Br J Radiol. 2001;74(885):818-20.

3. Busigo JP, Eftekhari F. Encysted spermatic cord hydroceles: a report of three cases in adults and a review of the literature. Acta Radiol. 2007;48(10):1138-42.

4. Wani I, Rather M, Naikoo G, Gul I, Bhat Z, Baba A. Encysted hydrocele of cord in an adult misdiagnosed patient underwent left inguinal exploration and the cyst was excised totally. All reported adult cases with $\mathrm{SCH}$ in the literature were summarized in Table 1.

Inconclusion, $\mathrm{SCH}$ is a rare clinical entity and data about $\mathrm{SCH}$ in adults is scarce. In literature, 10 adult $\mathrm{SCH}$ cases were reported previously. Age at diagnosis ranged between 22-69 years. US is an useful diagnostic tool to differentiate $\mathrm{SCH}$ from other causes of inguinal swelling. Encysted type of $\mathrm{SCH}$ can be differentiated from funicular type by using US. In symptomatic patients, encysted type of $\mathrm{SCH}$ can be treated with surgical excision. In funicular type, a repair of posterior wall of inguinal canal should be considered to avoiding uinalhernia after excision of $\mathrm{SCH}$.

\section{CONFLICTS OF INTEREST:}

Theauthorsdeclarenoconflict of interest. as irreducible hernia: a case report. Oman Med J. 2009;24(3):218-9.

5. Garg KM. Spermatic Cord Hydrocele In Adults: Experience of Three Cases. IOSR Journal of Dental and Medical Sciences (IOSR-JDMS). 2016;15(11):78-9.

6. D M, M KT, Khan DM. Encysted Spermatic Cord Hydrocele in a 60-year-old, Mimicking Incarcerated Inguinal Hernia: A Case Report. J Clin Diagn Res. 2014;8(2):153-4.

7. Bibekananda Mahapatra AP, Abhishek Mahadik, Qurratulain Chougle. Encysted hydrocele of the cord presenting as a groin swelling in an adult: a case report. International Journal of Research in Medical Sciences. 2015;3(9):2475-7. 